\title{
Anti-trust waiver for industrial research
}

\section{Justice blesses}

\section{inter-company collaboration}

\section{Washington}

The US Department of Justice has given the green light to research programmes jointly sponsored by two or more private companies, arguing that in general - and provided certain criteria are respected these should not conflict with the country's strict anti-trust legislation.

Uncertainty about the implications of anti-trust laws is often cited by US business as an obstacle to greater cooperation in research. Their concern is that, once a joint research project has been agreed and set up, they may be accused of violating legislation developed to ensure maximum competitiveness between rival companies.

As a result, anti-trust legislation was closely studied during last year's domestic policy review of industrial innovation, carried out under the auspices of the Office of Science and Technology Policy (OSTP) and the Department of Commerce.

Announcing the results of this review last November, President Carter said that by spurring competition, anti-trust policies could provide a stimulant to innovation, but he added that in some cases - such as research - industrial cooperation might have clear social and economic benefits for the country.

"Unfortunately our anti-trust laws are often mistakenly viewed as preventing all cooperative activity', $\mathrm{Mr}$ Carter said. And,rather than proposing any change to the law, he instructed the Department of Justice to publish a guide explaining its interpretation of the laws that already exist.

The guide was finally published in Washington last week. It is now being closely studied by companies and research associations contemplating joint research ventures, since, although not a legally binding document, it indicates how the department is likely to react to particular arrangements.

The guide should also help to clear the way for the creation of so-called Cooperative Generic Technology (COGENT) centres. These have been proposed by the Department of Commerce and the National Science Foundation, jointly funded by government and various industrial companies in fields such as welding, lubrication and powdered metal processing. The idea was approved by Congress in recently passed legislation.

The guide points out that there are various ways in which joint research

ventures could involve anti-trust considerations. For example, they could lead to market-dominating technology, to unfair collaboration between commercial competitors or to restrictive agreements on the use of research results.

Each of these might restrict open competition. At the same time, the guide says, competitiveness is a source of increased innovation - while innovation itself is a basis for commercial competitiveness - so that to discourage the one is to discourage the other.

So the challenge is to develop an arrangement that will maximize the rate of innovation (and hence competitiveness) by permitting research that would not otherwise be carried out, but in a way that does not give one or more companies an

\section{Science foundation all set at last}

\section{Washington}

As widely expectcd, the US National Science Foundation (NSF) has announced its intention to set up a new directorate for engineering, and to distribute responsibility for applied science - at present administered jointly with engineering - across the foundation's basic science directorates.

Announcing the planned reorganization to members of the National Science Board last week, NSF's director-designate, Dr John Slaughter, said that creating the new directorate meant that the foundation intended to seek more resources for the engineering disciplines.

The reorganization is the result of discussions that have been taking place within NSF since early in the summer, and are partly in response to outside criticism that NSF has not been doing enough to encourage engineering research, with the result that engineering has suffered in comparison with more traditional basic science disciplines.

At the same time, NSF has dropped a proposal that had also been under discussion to set up a new directorate for social science, at present linked with the biological and behavioural sciences. Although many researchers had argued that such a move could help to enhance the academic status of social science research, administrators had voiced fears that it might increase the visibility of the social science research budget - and hence its vulnerability to congressional budget cuts.

According to Dr Slaughter, the new reorganization means that although basic research remains the central mission of NSF, the base of support for applied research will be broadened, since all research directorates will now support applied research projects while keeping their basic research programmes more or less in being.

In addition, the reorganization would unfair advantage over others in the same field.

Rather than providing any hard and fast rules on how this should be done, the Department of Justice offers general guidance on how it would probably interpret existing statutes in particular situations. And it includes eight hypothetical case studies intended to illuminate its position.

As far as basic research is concerned, the department says that cooperation is unlikely to be much of a problem, since the competitive significance of the research is likely to be largely speculative and, as the results would be published in the open literature, there should be few problems about equal access by other companies.

David Dickson

give new emphasis to engineering research and education, Dr Slaughter told the members of the National Science Board, which is formally responsible for the activities of NSF and had previously endorsed the reorganization proposals.

NSF officials hope that, by giving engineering research a new emphasis, they will be able to head off plans to set up a National Technology Foundation, contained in a bill introduced to the House of Representatives by $\mathrm{Mr}$ George Brown, chairman of the House Science and Research Subcommittee.

In a letter to Dr Donald Langenberg, acting NSF director, Mr Brown said that Congress might conclude, in studying the technology foundation concept, that "existing mechanisms to improve the state of technology are not able to handle current challenges, and that major programme dislocations are not too high a price to pay for a fundamental programme reorientation".

Several members of the engineering research community, while welcoming NSF's greater emphasis on engineering, have been saying that this will only improve the situation for engineering research, which now receives only about 10 per cent of the NSF's budget, if it results in more money being made available by Congress.

David Dickson

\section{Nuclear power}

\section{Border problems}

\section{Brussels}

France's policy of siting nuclear power stations on its frontiers has aroused antagonism both in the European Parliament and among environmental groups. The European parliament met on 19 November to discuss a report by Mechthild von Alemann (German, Liberal) which reflected the concern over the French government's pians to build 
further power stations at $\mathrm{Chooz}$ and Cattenoom, close to the Luxembourg and Belgian borders.

The previous day, environmental groups from Luxembourg, France and Belgium had called a press conference in Luxembourg and denounced the French government's total disregard for the principles and rules of international law. The French, however, are not the only culprits. Of the 120 or so nuclear power stations at present in operation, under construction or planned in the European Community, 33 are less than 25 miles from national borders and another 15 are less than 6 miles from borders.

Von Alemann's report urges the introduction of Community safety norms and the implementation of a Community consultation procedure, bolstered by an EEC regulation. During the debate many speakers called for a broader interpretation of Articles 37 and 41 of the Euratom Treaty. These relate to the obligation of member states to supply the European

\section{French take Manhattan}

A French firm has stormed the US optical communications market - and installed a $6.5-\mathrm{km}$ optical fibre system in Manhattan. CIT-Alcatel, the leading French telecommunications company, announced last week that it had beaten off competition - including the giant ITT - to supply the link to Western Union cable and telegraph company. They system will be the first fully operational optical fibre link in the United States CIT officials believe.

CIT will also supply the second such link, an experimental one which the company sold to Western Union a year ago. When the new link, which uses light emitting diodes to convert electrical signals into light, goes into operation in January, the experimental link (which uses laser diodes) will also be put into regular use. CIT will thus gain operating experience with the two principal competing technologies for optical fibre input.

The great advantage of optical fibre systems for Manhattan is that available cable ducts under the city are physically crammed to capacity, and it is now almost impossible to feed through standard electrical links. Optical fibre links, however, can be made on cables 10 times smaller in outer diameter - allowing a hundredfold increase in channel capacity for the same duct cross-section.

The CIT system uses cables, supplied by another company, of $1 \mathrm{~cm}$ outer diameter to carry 44 megabits per second (672 telex channels). CIT supplied the input-output devices and the data management systems for the link. CIT considers that this first step in the US market is "fundamental" and that the potential scale of the market is "huge".

Robert Walgate
Commission with all data on radioactive effluent capable of causing pollution and details of all future plans for nuclear power stations.

French parliamentarians of all political hues united against the attack, claiming that it compromised national sovereignty. Pierre Calvez (French, Liberal) said he was opposed to any Community decision which transcended national policy. He added that all new power stations were subject to bilateral agreements and international regulations.

Speaking on behalf of the European Commission, acting Energy Commissioner Etienne Davignon declared that France had not infringed the Euratom Treaty and that the treaty could not be interpreted in such a light as to give the Commission the right to interfere.

Stanley Johnson (UK, Conservative) reminded the parliament of the fate of the so-called Séveso Directive at the last meeting of the Environment Council in June. The draft directive on the prevention of major accidents was not adopted because the French objected to the provisions for transboundary notification procedures. A compromise formula over this problem is now being thrashed out and it is hoped that the next council meeting on 12 December will adopt the text.

The EEC's energy ministers, when they met in Brussels on 27 November, briefly discussed the problems associated with the siting of nuclear power stations near boundaries. The draft regulation on the Community consultation procedure for electricity power stations that affect the territory of another member state has been held up in the council for several years. It now seems likely that this regulation will be looked at more seriously and its progress accelerated.

Jasper Becker

\section{Soviet health}

\section{More research}

A high-level cooperation programme between Soviet scientists and doctors will be an important feature of the next Five Year Plan for public health. This was decided by a joint session of the Academy of Sciences and the Academy of Medical Sciences last month. An interdepartmental scientific council is to be established, and a joint research programme is being drawn up. This says Academician Anatolii Aleksandrov, president and chairman of the new council of the Academy of Sciences, will reflect the main problems in public health and take into account the potential of the country's scientific institutes.

Aleksandrov reported that cooperation between scientists and medical teams has already led to some major advances, including medical applications of ultrasonics, cryogenics and laser technology. The Minister of Public Health, Boris Petrovskii, spoke warmly of the raised standards of diagnosis and treatment made possible by the introduction of new techniques in cardiology, oncology, surgery, paediatrics and pharmacology.

Molecular biology, which until the mid-1970s was neglected in the Soviet Union, received a glowing tribute from Dr. Nikolai Blokhin, President of the Academy of Medical Sciences. Recent results, he said, opened up prospects for the establishment of new ideas about the nature of viruses, malignant changes in cells, human heredity and the development of genetic engineering techniques. Other innovations are less welcome. The MarxistLeninist world outlook, said Blokhin, protected Soviet medicine from mysticism, parapsychology, the psychosomatic theories of Freud, various types of neoFreudianism and other "views that could lead medicine astray". He called therefore for greater cooperation between medical workers and representatives of the philosophical institutes of the Academy of Sciences.

Vera Rich

\section{Polish science}

\section{Advice not taken}

The Gierek regime consistently "torpedoed or disavowed" constructive criticisms from its nine-person team of scientific advisers. So claims Professor Alojzy Melich, a member of the team since its inauguration in 1977, in an interview in Trybuna Robotnicza, the daily paper of Katowice (Mr Gierek's home power-base).

Professor Melich said that during the past three years, the team had prepared about a dozen comprehensive surveys on the main problems facing the country, as well as numerous smaller papers and analysis. These, however, were rejected by the government and the planning commission, simply because they attacked current policies. In the end, Professor Melich said, the government simply stopped providing its scientific advisers with any information at all.

This is not the first such accusation to be levelled in recent months. In August, an $a d$ hoc farmers' committee which has since become the nucleus of the farmers' campaign for trade union representation, accused the authorities of suppressing expert reports on the deterioration of Polish agriculture. Unlike most critics, however, Professor Melich did not condemn Mr Gierek's policy of obtaining massive foreign loans to back his investment projects; these, said Melich, had provided an important stimulus for the economy.

The current economic crisis, however, has meant that the future of many major investment projects has become doubtful. Even the much hailed Programme-Wisla is liable to suffer some cutbacks at least for the present. This scheme, which was envisaged as a major contribution to Poland's economy in the twenty-first century, consists of a broad range of water- 